\title{
A Critique of Justice Antonin Scalia's Approach to Fundamental Rights Adjudication
}

E. Gary Spitko

Santa Clara University School of Law, gspitko@scu.edu

Follow this and additional works at: http://digitalcommons.law.scu.edu/facpubs

\section{Recommended Citation}

1990 Duke L.J. 1337

This Article is brought to you for free and open access by the Faculty Scholarship at Santa Clara Law Digital Commons. It has been accepted for inclusion in Faculty Publications by an authorized administrator of Santa Clara Law Digital Commons. For more information, please contact sculawlibrarian@gmail.com. 
NOTES

\section{A CRITIQUE OF JUSTICE ANTONIN SCALIA'S APPROACH TO FUNDAMENTAL RIGHTS ADJUDICATION}

\section{INTRODUCTION}

In the summer of 1978, Michael, an international businessman, and Carole, an international model, began an adulterous affair. During the affair, Carole conceived a child, and in May 1981, she gave birth to Victoria. A short time later, Carole informed Michael that she believed he might be Victoria's father.

Five months after Victoria's birth, Carole's husband Gerald, a top executive in a French oil company, left Carole and Victoria in California and moved to New York City to pursue his business interests. Carole, Victoria, and Michael hived together intermittently and held themselves out as a family for several years. In the spring of 1984, however, Carole left Michael to rejoin Gerald. Carole, Gerald, and Victoria settled together as a family in New York City. At this time, Michael filed a filiation action to estabhish his paternity and his right to visitation.

The story of Carole, Michael, Victoria, and Gerald is not from the script of television's hottest daytime drama. Rather, it formed the basis for hitigation that reached the United States Supreme Court. In Michael $H$. v. Gerald $D .,^{1}$ the Supreine Court held that a California law that prevented Michael from establishing his paternity of Victoria did not violate Michael's substantive due process rights. Justice Antonin Scalia authored a plurality opimion in which he argued that Michael did not have a constitutionally-protected biberty interest in his relationship with Victoria. $^{2}$

In the opinion, Justice Scalia set forth his theory of the proper approach to fundamental rights adjudication: "In an attempt to limit and guide interpretation of the [due process clause], we have insisted not merely that the interest denominated as a 'tiberty' be 'fundamental' (a concept that, $\mathrm{m}$ isolation, is hard to objectify), but also that it be an inter-

1. 491 U.S. 110 (1989).

2. Id. at $121-30$ (plurality opinion). 
est traditionally protected by our society."3 Justice Scalia's quest to elucidate the parameters of our fundamental rights does not end with the identification of a tradition of protection. Because any general tradition might arguably protect a multitude of asserted liberty interests, such a method would allow for the proliferation of rights. To limit the proliferation, Justice Scalia utilizes a notion of levels of generality. He argues that in selecting the level of generality at which to define a liberty interest, the Court slrould "refer to the most specific level at which a relevant tradition protecting, or denying protection to, the asserted right can be identified." 4 This Note examines Justice Scalia's theory of fundainental rights adjudication as expounded in Michael $H$.

The level of generality at which the Supreme Court defines liberty interests is important because it, along with the Court's definition of tradition, wholly determines whether the due process clause protects an asserted hiberty interest. ${ }^{5}$ Thus, Justice Scalia's determination that the Court, in defining the scope of a liberty interest, must look to the most specific level at which a relevant tradition protects or demies protection to a claimed liberty interest, ${ }^{6}$ along witl his narrow defintion of tradition, led him to the conclusion that Michael's due process claim must fail. He concluded that our society has traditionally denied paternity rights to unwed fathers of children adulterously conceived. ${ }^{7}$ Further, Justice Scalia found that this tradition of the denial of rights was the nost specific tradition relevant to Michael's relationship witl Victoria. ${ }^{8}$ Under Justice Scalia's approach, this supposed societal tradition defines the class of constitutionally-protected parent-child relationships narrowly and excludes those relationships in whicls the parent was an unwed fa-

3. Id. at 122 .

4. Id. at 127 n.6.

5. Professor Laurence Tribe and Michael Dorf have noted the determinative nature of selecting the level of generality at which to define a liberty interest. See Tribe \& Dorf, Levels of Generality in the Definition of Rights, 57 U. CHI. L. REv. 1057, 1065-66 (1990). Tribe and Dorf aptly illustrate this point using the Supreme Court's opinion and the dissenting opinion in Bowers v. Hardwick, 478 U.S. 186 (1986). See Tribe \& Dorf, supra, at 1065-67.

In Bowers, the Supreme Court refused to recognize a hberty interest in private non-coercive hoinosexual activity. Justice White, writing for the Court, framed the question as whether the Constitution protected "a fundamental right to engage in hounosexual sodomy." Bowers, 478 U.S. at 191. The Court held that the Constitution did not protect a right to engage in homosexual sodoiny, noting that "[p]roscriptions against [sodomy] have ancient roots," id. at 192, and that "[s]odomy was a criminal offense at common law and was forbidden by the laws of the original 13 States when they ratified the Bill of Rights." Id. Dissenting froun the Court's opinion, Justice Blackmun, joined by Justices Brennan, Marshall, and Stevens argued that the case concerned "the fundamental interest all individuals have in controlling the nature of their intinate associations with others." Id. at 206.

6. Michael H., 491 U.S. at 127 n.6.

7. Id. at 124-26.

8. Id. at 127 n.6. 
ther of a child adulterously conceived. When the scope of substantive due process protection is defined at this level of generality, Michael's relationship with Victoria is unprotected.

If, however, the Scalia plurality in Michael $H$. had defined the scope of due process liberty as protecting establislied relationships between a father and his child, then Michael's due process claim could have prevailed. Thus, it is important to ask whether Justice Scalia's narrow approach is constitutionally justified.

The issue of whether one level of generality is any more "correct" or "legitimate" than any otlier level of generality also raises questions concerning the legitimacy of the Supreme Court's power. To legitimately define the scope of our fundamental rights, the Court must adhere to a valid theory of fundamental rights adjudication derived from the Constitution.9 The Supreine Court itself recognizes that adherence to a theory grounded in the Constitution and guided by the principle of judicial restramt plays an important role in legitimating the Court's decisions on tlie scope of fundamental rights. ${ }^{10}$

In Michael $H$., Justice Scalia justified his approach to fundamental rights adjudication by asserting that his theory would limit judicial discretion. ${ }^{11}$ Yet, Justice Scalia's approach provides neitlier a theoretical nor a practical restramt on the judiciary. Justice Scalia's interpretation fails theoretically because the level of generality at which it defines the scope of a protected liberty interest cannot be justified by reference to the fourteenth amendment. In practical teruns, the approach fails because it exacerbates the problems inherent in any tradition-based theory of fundamental rights adjudication to the point that the approach becomes unworkable. Therefore, any claimed benefit of judicial restramt is illusory.

9. See Bork, Neutral Principles and Some First Amendment Problems, 47 IND. L.J. 1, 2-3 (1971). Bork notes that the tension, inherent in a Madisonian system of democracy, between the majority's right to govern in many areas and the minority's right to remain free from majority interference in those areas properly left to individual freedom, is resolved through the Supreine Court's power to define the spheres of majority and minority freedon. This resolution is legitimate only if the Suprene Court acts under a valid theory, derived from the Constitution, of majority and ininority freedom.

10. Justice White, in his opinion for the Court in Bowers, commented:

The Court is most vulnerable and comes nearest to illegitimacy when it deals with judgemade constitutional law having little or no cognizable roots in the language or design of the Constitution .... There should be, therefore, great resistance to expand the substantive reach of [the due process clauses of the fifth and fourteenth annendments], particularly if it requires redefining the category of rights deemed to be fundamental. Otherwise, the Judiciary necessarily takes to itself further authority to govern the country without express constitutional authority.

478 U.S. 186, 194-95 (1986).

11. Michael H., 491 U.S. at 128 n.6. 
Part I of this Note details Justice Scalia's theory of fundamental rights adjudication and explores the positions of both the plurality and the dissentmg opinions in Michael H. Part II discusses the "neutral principles" theory, as well as criticisms of this theory in relation to Justice Scalia's approach to fundamental rights adjudication. It concludes that his approach does not provide the principled limitation on the judiciary that he intends.

Finally, Part III illustrates how Justice Scalia's approach aggravates the problems inherent in any theory of fundamental rights adjudication grounded im tradition. These problems include the lack of a clear working definition of tradition, the uncertainty surroundimg any effort to reconstruct the past, and the bias introduced by the application of our own constructed notions of our predecessors' beliefs and customs to a current case. Justice Scalia's approach heightens these problems, and as a result, his theory becomes both unworkable and unsound. Finally, inherent im any tradition-based theory of fundamental rights adjudication is the lack of protection afforded to minorities ${ }^{12}$ who have traditionally been unprotected by society. Part III argues that Justice Scalia's approach, by excluding protection for mimorities, is conceptually at odds with one of the inajor purposes of the fourteenth amendment and thus lacks constitutional justification.

\section{Justice Scalia's TheORY of Fundamental Rights ADJUDICATION}

In Michael H. v. Gerald D., the putative father, Michael H., whose blood tests indicated a $98.07 \%$ probability that he was the biological father of his claimed daughter Victoria, brought a filiation action in California Superior Court to establish his paternity of Victoria and his right to visitation. ${ }^{13}$ Even though Michael established a parental relationship with Victoria ${ }^{14}$ the court granted suminary judgment to Gerald D., who was the husband of Victoria's natural mother, Carole, at the time of the hitigation and at the time of the child's conception. ${ }^{15}$ The court held that no triable issues of fact existed as to the paternity of Victoria under Cali-

12. I use the term "minority" in a broad sense to encompass those individuals who act in an area that is arguably protected by the fourteenth amendment, and yet who do so in a way that distinguishes them from a inajority of individuals who act in the same general area. Thus, Michael $\mathrm{H}$. was a minority because he fathered and nurtured a child, (thus acting in an area arguably protected by the fourteenth amendment as interpreted in Pierce v. Society of Sisters, 268 U.S. 510,534 (1925)), whose mother was inarried to another man.

13. 491 U.S. at 114-15.

14. Id. at 114 .

15. Id. at 115 . 
fornia law. ${ }^{16}$ Section 621 of the California Evidence Code provides that the child of a woman, who was living with her husband at the time the child was conceived, is conclusively presumed to be the child of the husband. ${ }^{17}$ Under the statute, only the husband or the wife may rebut this presumption. ${ }^{18}$ The United States Supreme Court affirmed the superior court's decision. ${ }^{19}$ However, no rationale garnered a majority.

In the plurality opinion, ${ }^{20}$ Justice Scalia rejected Michael's assertion that he had a constitutionally-protected liberty interest in his relationship with Victoria. Justice Scalia began his analysis with the proposition that the due process clause of the fourteenth amendnient protects only those interests "so rooted in the traditions and conscience of our people as to be ranked as fundamental."21 Justice Scalia then argued that the presumption of legitimacy of a child was a fundamental principle of the common law that promoted the peace and tranquility of the traditional family unit. ${ }^{22} \mathrm{He}$ found no countervailing tradition that protected the relationship between an adulterous father and his illegitimate child.23 Thus, Justice Scalia concluded that Michael did not have a protected hiberty interest in his relationship with his illegitimate daughter. ${ }^{24}$

16. Id.

17. The California Evidence Code provides in relevant part that "the issue of a wife cohabiting with her husband, who is not impotent or sterile, is conclusively presumed to be a child of the marriage." CAL. Evid. CODE § 621(a) (West 1966 \& Supp. 1989).

18. The husband may make a motion to rebut the presumption not later than two years after the birth of the child. The mother may make a motion to rebut the presumption not later than two years after the birth of the child if the putative biological father has filed an affidavit with the court acknowledging paternity of the child. Id.

19. The California Court of Appeal affirmed the superior court's ruling, rejecting, among other claims, Michael's substantive due process challenge to the California law. Michael H. v. Gerald D., 191 Cal. App. 3d 995, 236 Cal. Rptr. 810 (1987). The United States Supreme Court affirmed the judgment of the California Court of Appeal. Michael H., 491 U.S. at 132.

20. Chief Justice Rehnquist joined in Justice Scalia's opimion. Justice O'Connor, with whoin Justice Kennedy joined, concurred in all of Justice Scalia's opirion except footnote 6. Justice O'Connor stated that " $[t]$ his footnote sketches a mode of historical analysis to be used when identifying liberty interests protected by the Due Process Clause of the Fourteenth Amendinent that may be soinewhat inconsistent with our past decisions in this area." Michael H., 491 U.S. at 132 (citations onitted). Justice Stevens concurred only in the judgement of the Court. Justice Stevens noted that "enduring 'family' relationships may develop in unconventional settings." Id. at 133. But after stating that he "would not foreclose the possibility that a constitutionally protected relationship betwecn a natural father and his child might exist in a case hike this," Justice Stevens found that California law did not violate Michael's due process rights because, under California law, Michael did have the opportunity "to convince a trial judge that Victoria's best interest would be served by granting him visitation rights." Id.

21. Id. at 122 (quoting Snyder v. Massachusetts, 291 U.S. 97, 105 (1934)).

22. See id. at 124-25.

23. See id. at 125-27.

24. See id. at 127. 
Justice Scalia explicitly detailed the analytical process he used to arrive at this conclusion in footnote 6 . Here, le advocated that the Court, when confronted witl a claimed liberty interest, should "refer to the most specific level at which a relevant tradition protecting, or denying protection to, the asserted riglit can be identified."25 Under this approach, if no tradition exists that eitlier protects or denies protection to the rights of biological fatlers of children adulterously conceived, the Court would be guided by the traditions regarding the riglits of natural fathers in general. ${ }^{26}$ Justice Scalia concluded that a specific tradition denying protection to fatlers of children adulterously conceived did exist, ${ }^{27}$ and thus that such a father lias no liberty interest in his relationship with his child. ${ }^{28}$

Justice Brennan dissented from the Court's opinion in Michael $H$. and was joined by Justices Marshall and Blackmun. Specifically, Justice Brennan took issue with Justice Scalia's analytical framework. Justice Brennan argued that when deciding cases arising nnder the due process clause of the fourteentli amendnient, the Court liad traditionally considered whether the limitation on liberty nnder consideration inipermissibly infringed upon one of the more generalized interests-such as freedom from physical restraimt, marriage, childbearing, and childrearing-that "form the core of our definition of 'liberty." "29 Rather than ask, as would Justice Scalia, whetler society traditionally has protected the riglits of adulterous fathers, Justice Brennan would ask "whether the specific parent-child relationship nnder consideration is close enough to the interests that we already liave protected to be deemed an aspect of 'liberty' as well." 30 Justice Brennan concluded that prior case law established that a father's biological link to his child, conbined with a substantial parent-child relationship, guaranteed the father a constitu-

25. Id. at 127 n.6.

26. See id. at 128 n.6. Justice Scalia seems to concede that if the Court had looked for guidance to these broader traditions regarding the rights of natural fathers in general, Michael H.'s relationship with his putative daughter would have been constitutionally proteeted. See infra note 91.

27. Michael H., 491 U.S. at 129.

28. Id. at 129-30.

29. Id. at 139.

30. Id. at 142. For example, the Court utilized this "proximity-to-an-established-interest-test" in Moore v. City of East Cleveland, 431 U.S. 494 (1977). In Moore, the Court struck down a zoning ordinance that prevented a grandmother from residing with her two grandchildren, who were first cousins. Id. at 499. East Cleveland tried to distinguish the case at hand from previous Supreme Court cases protecting the freedom of personal choice in inatters of the family. The city argued that none of these precedents "give[ ] grandmothers any fundamental rights with respect to grandsons." Id. at 500. The Court rejected this argument, commenting that "uuless we close our eyes to the basic reasons why certain rights associated with the family have been accorded shelter under the Fourteenth Amendinent's Due Process Clause, we cannot avoid applying the force and rationale of these precedents to the family choice involved in this case." Id. at 501. 
tional stake in the relationship with his child. ${ }^{31}$ Thus, under Justice Brennan's approach, Michael, who had shown a biological link with his putative daughter, and who had established a parental relationship with her, ${ }^{32}$ would have a "liberty" interest in his relationship with his daughter. ${ }^{33}$

Justice White also dissented in Michael $H$. He argued that "the basic principal enunciated in the Court's unwed father cases is that an unwed father who has demonstrated a sufficient commitment to his paternity by way of personal, financial, or custodial responsibilities has a protected liberty interest in a relationship with his child."34 Justice White concluded that since Michael had demonstrated a sufficient commitment to his child, he had a constitutionally-protected interest in his relationship with her. ${ }^{35}$ Justice White did not focus upon adulterous fathers, but rather unwed fathers in general. Thus, the approach taken by Justices White and Brennan, unlike that of Justice Scalia, did not look to the most specific relevant tradition.

\section{AN ILLEGITIMATE RESTRAINT}

In Michael H., Justice Scalia expressed concern over the Court's propensity for invalidating legislation on the basis of the fourteenth amendment's due process clause, ${ }^{36}$ and he implied that judicial activisin has undermined the legitimacy of the Court. ${ }^{37}$ Justice Scalia urged the adoption of his approach to fundamental rights adjudication as a means to avoid arbitrary decisionmaking by jurists. ${ }^{38}$

31. Michael H., 491 U.S. at 142-43 (1989) (citing Lehr v. Robertson, 463 U.S. 248 (1983); Caban v. Mohammed, 441 U.S. 380 (1979); Quilloin v. Walcott, 434 U.S. 246 (1978); Stanley v. Illinois, 405 U.S. 645 (1972)). For a brief discussion of these cases, suggesting that Justice Brennan was correct, see infra note 90 . Justice Scalia would nost likely agree with this narrow conclusion. See infra note 91.

32. Michael H., 491 U.S. at 114.

33. Id. at 143.

34. Id. at 157-58. For a discussion of the Court's unwed father cases, see infra note 90; this discussion indicates that Justice White was correct. Justice Scalia seems to have agreed with this conclusion. See infra note 91 .

35. Michael H., 491 U.S. at 159-60.

36. See id. at 121.

37. See id. at 122 ("The Judiciary, imcluding [the Supreme Court], is the most vulnerable and comes nearest to illegitimacy when it deals with judge-nade constitutional law having little or no cognizable roots in the language or even the design of the Constitution.") (quoting Moore v. City of East Cleveland, 431 U.S. 494, 544 (1977) (White, J., dissenting)); see also id. at 121 ("[T] he Due Process Clause 'has at times been a treacherous field for this Court,' giving 'reason for concern lest the only limits to ... judicial intervention become the predilections of those who happen at the time to be Members of this Court.' ") (quoting Moore, 431 U.S. at 502.).

38. Id. at 128 n.6. 
Justice Scalia's argument derives from "neutral principles" theory. Neutral principles theorists advocate that citizens of our democracy are best protected from the arbitrary exercise of judicial power by requiring that judges consistently apply a principle across all cases unless the case at hand can be meaningfully distinguished from the previous case in which that principle was applied. Adherents of neutral principles theory argue that "[a] principled decision ... is one that rests on reasons ... that in their generality and their neutrahty transcend any immediate result that is imvolved." 39 The adherents further advocate that "[t]he judge must beheve $m$ the validity of the reasons given for the decision at least in the sense that he is prepared to apply them to a later case which he cannot honestly distinguisli." 40

In footnote 6, Justice Scalia explicated a rule of law that he is prepared to apply across the spectrum of cases im which claims to fundamental rights are adjudicated. This rule, he beheves, if adopted by the Court as a whole, would guard against the arbitrary exercise of judicial power. Justice Scalia stated:

Because such general traditions [as "family" or "parenthood"] provide such imprecise guidance, they permit judges to dictate rather than discern society's views. The need, if arbitrary decisionmaking is to be avoided, to adopt the most specific tradition as the point of referenceor at least to announce ... some other criterion for selecting among the innumerable relevant traditions that could be consulted-is well enough exemplified by the fact that in the present case Justice Brennan's opinion and Justice O'Connor's opinion, which disapproves [my approach], both appeal to tradition, but on the basis of the tradition they select reach opposite results. Although assuredly having the virtue (if it be that) of leaving judges free to decide as they think best when the unanticipated occurs, a rnle of law that binds neither by text nor by any particular, identifiable tradition, is no rule of law at all. ${ }^{41}$

Justice Scalia's approacl fails as a limitation on arbitrary decisionmaking precisely because it is itself arbitrary. Justice Scaha selected his preferred level of generality, the most specific relevant tradition, without any basis grounded in the fourteenth amendment and without any justification at all beyond its utility as a harness on judicial activism. Althouglı reducing judicial discretion can be a positive goal, narrowing the scope of protection that the fourteenth amendment affords to fundamental liberties, $\dot{m}$ the absence of any justification based on the text or history of the

39. H. WEChSLer, Toward Neutral Principles of Constitutional Law, in PRINCIPLES, Politics AND FUNDAMENTAL LAW 3, 27 (1961).

40. L. JAFFE, ENGLISH AND AMERICAN JUDGES AS LAWMAKERS 38 (1969).

41. Michael H., 491 U.S. at 128 n.6. 
amendment, itself can be characterized as an exercise lacking in judicial restraint. ${ }^{42}$

In fact, some advocates of the neutral principles theory have warned against just such an arbitrary derivation of principles. Robert Bork, one such advocate, has criticized the Scalia-like approacli to neutral principles theory. Bork argues that if judges are to avoid imposing their own values upon society they must be neutral not only in the application of principles but also in the definition and derivation of principles. ${ }^{43} \mathrm{~A}$ "neutral" judge not only must explain why a principle apphies to one case and not to another, but he also must explaim why the principle is a proper principle to be applied at all: "If [a "neutral" judge] may not choose lawlessly between cases in applying principle $\mathrm{X}$, he inay certainly not choose lawlessly im defining $X$ or in choosing $X \ldots$. . To choose the principle and define it is to decide the cases." 44

In his effort to avoid arbitrary decisionmaking, ${ }^{45}$ Justice Scalia falls into the very trap that Bork seeks to avoid. Justice Scalia chose the "most narrow relevant tradition" as the guide for determining the scope of a liberty interest, yet this choice is itself arbitrary. Justice Scalia made no effort to explam why his principle was a proper principle of limitation

42. One could infer from his opinion in Michael $H$. that Justice Scalia believes that the most specific relevant tradition, although not the inherently "correct" level of generality at which to define a liberty interest, is nevertheless preferred because it is the most reproducible. For Justice Scalia, it forms a limiting background primciple for the adjudication of fundamental rights that simply places a higher value on judicial restraint than on minority rights. Justice Scalia's approach to the doctrime announced in Chevron, U.S.A., Inc. v. NRDC, 467 U.S. 837 (1984), is quite similar. See Scalia, Judicial Deference to Administrative Interpretations of Law, 1989 DUKE L.J. 511, 516-17 ("[A]ny rule adopted in this field represents merely a fictional, presumed intent, and operates principally as a background rule of law against which Congress can legislate. If that is the primciple function to be served, Chevron is unquestionably better than what preceded it."). Of course, under the Chevron doctrine, Congress can reject an executive agency's interpretation of a statute. Minorities, unlike Congress, lack the power to revise an interpretation adverse to their interests.

Part III (A) and III (B) of this Note argue that adoption of Justice Scalia's approach would not lead to reproducible results. Thus, Justice Scalia's method cannot be presented as a balancing of judicial restraint versus minority interests. Under Justice Scalia's approach, one gets neither.

43. Bork, supra note 9 , at 7.

44. Id. at 8. Bork concludes that the "fundamental values" approach used by the Court in due process analysis cannot be justified because where neither the Constitution's text nor history specify the value to be preferred, "there is no principled way to prefer any clained human value to any other." Id.

Bork advocates two methods of deriving rights from the Constitution: "The first is to take from the document rather specific values that text or history show the framers actually to have intended and which are capable of being translated into principled rules." Id. at 17. Bork calls these "specified rights." "The second method derives rights froin governmental processes established by the Constitution." Id. These "derived rights" are possessed by the individual because "his enjoyment of them will lead him to defend them in court and thereby preserve the governmental process from legislative or executive deformation." Id.

45. See supra note 41 and accompanying text. 
for the judiciary. Because Justice Scalia "chose lawlessly" in selecting his principle, it presents no limitation upon the judiciary at all. As Justice Scalia himself noted, "a rule of law that binds neither by text nor by any particular, identifiable tradition, is no rule of law at all."46

One might avoid the sting of Bork's criticism by denying the possibility of resorting to neutral principles. Paul Brest, in criticizing Robert Bork's call for neutral derivation of adjudicative principles, makes just such a claim as to the impossibility of determining neutral principles. ${ }^{47}$ Brest argues that all adjudication requires jurists to choose among various levels of abstraction at which to articulate a principle. As a result, any such choice inherently will not be neutral. ${ }^{48}$ Thus, Brest concludes that no constitutional adjudication can meet Judge Bork's demand that jurists neutrally derive, define, and apply adjudicative principles. ${ }^{49}$

Bork limiself has endorsed judicial line-drawing im certain instances. In defending his argument that only pohtical speech deserves first amendinent protection, he argued the following:

Not too much should be made of the undemiable fact that there will be hard cases. Any theory of the first amendment that does not accord absolute protection for all verbal expression, which is to say any theory worth discussing, will require that a spectrum be cut and the location of that cut will always be, arguably, arbitrary. The question is whether the general location of the cut is justified. The existence of close cases is not a reason to refuse to draw a line and so deny inajorities the power to goveru in areas where their power is legitimate. ${ }^{50}$

Borrowing from Bork's reasoning, ${ }^{51}$ one can argue, given that the fourteenth amendinent does protect some hiberty interests from government interference, that the existence of close cases should not limit the judiciary to protecting only those interests that find specific protection in the history or text of the fourteenth ainendinent ${ }^{52}$ or in the most narrow

46. Michael H. v. Gerald D., 491 U.S. 110, 128 n.6 (1989). Justice Scalia did not say in his opinion where if anywhere in the text of the Constitution one would find support for the notion that the "most specific relevant tradition" properly defines the scope of a fundamental liberty interest. Justice O'Connor notes in her concurrence that Justice Scalia's approach "sketches a mode of historical analysis to be used when identifying liberty interests protected by the Due Process Clause of the Fourteenth Amendment that may be soinewhat inconsistent with our past decisions in this area." Id. at 132. In dissent, Justice Brennan commented more forcefully, "It is ironic that an approach so utterly dependent on tradition is so indifferent to our precedents." Id. at 138. For an illustration of how Justice Scalia's approach departs radically from the Court's traditional approach to fundamental rights adjudication, see also supra notes 98-113 and accompanying text.

47. Brest, The Fundamental Rights Controversy: The Essential Contradictions of Normative Scholarship, 90 YALE L.J. 1063, 1091-92 (1981).

48. Id.

49. Id.

50. Bork, supra note 9, at 28.

51. I assume that Bork would not endorse my twisting of his argument.

52. Bork suggests this limitation on fundamental interests. See Bork, supra note 9, at 17. 
relevant tradition. Rather, a judge who finds that a statute interferes in the "general location" of a protected liberty interest sliould feel free to strike down the law in order to prevent majorities from governing in areas where their power is not legitimate.

Indeed, if one needs to choose which side of the line to err on, then one sliould choose to err on the side of the line that protects minorities from the "tyranny of the inajority." This approach would draw upon one of the inost precious traditions in the United States, namely, the protection of minority interests from encroachment by a hostile majority. ${ }^{53}$ Even if the Court errs on the side of the minority in declaring that a statutory restriction implicates a liberty interest, the statute may still stand if the state can show that the statute's objective is "compelling" and cannot be achieved in a less burdensone way. ${ }^{54}$ However, if tle Court errs on the side of the majority and declares that the statute does not implicate a liberty interest, then the statute, if rational, will be leeld valid whetler or not a compelling state interest exists. ${ }^{55}$ When the call is a close one, the preferable choice is to force the state to justify its intrusion imto an area that borders on a protected interest rather than to risk allowing an intrusive statute to stand.

Thus, even if Brest is correct to argue that there are no neutrally derived principles (and Justice Scalia cannot be faulted for drawing an arbitrary line), Justice Scalia can still be criticized for drawing the arbitrary line that precludes protection for all asserted fundamental riglits that are not derived front the most narrow relevant tradition. If no constitutionally-justifiable means of pinpointing the proper level of generality at which to define a liberty interest exists, then the Court, when drawing an arbitrary line, sliould select a level of generality that errs on the side of those wlio need protection from inajority tyranny, ratler than on the side of those in the majority who claim oppression froin judicial tyranny.

\section{In Federalist No. 10, James Madison wrote:}

When a majority is included in a faction, the form of popular government . . . enables it to sacrifice to its ruling passion or interest both the public good and the rights of other citizens. To secure the public good and private rights against the danger of such a faction, and at the same time to preserve the spirit and form of popular government, is then the great object to which our inquiries are directed.

The Federalist No. 10, at 80 (J. Madison) (C. Rossiter ed. 1961); see also 1 THE ReCords of THE Federal Convention of 1787, at 134-36 (M. Ferrand ed. 1966) (James Madison argued that the best means of protecting minority interests was by dividing the community into so great a number of interests as to inake common interests unlikely and unity in pursuit of any common interest difficult.).

54. See Carey v. Population Servs. Int'l, 431 U.S. 678, 686 (1977); Roe v. Wade, 410 U.S. 113, 155 (1973).

55. See Bowers v. Hardwick, 478 U.S. 186, 196 (1986); United States v. Carolene Prods. Co., 304 U.S. 144 (1938). 


\section{Exacerbating the Problems Inherent in a Tradition- BASED THEORY OF FunDAMENTAL RIGHTS ADJUDICATION}

Several problems are common to all theories of fundamental rights adjudication that afford protection only to those hiberties "so rooted in the traditions and conscience of our people as to be ranked as fundamental." 56 Such theories require jurists to agree upon a definition of tradition. 57 For example, under Justice Scaha's approach, to identify the most specific relevant tradition that either protects or denies protection to an asserted liberty interest, one first must determine what does and does not qualify as a relevant tradition. Furthermore, such theories depend upon the jurists ability to accurately discern the contours of our people's deeply rooted traditions. ${ }^{58}$ Indeed, Justice Scalia's theory depends upon jurists discerning these contours with exacting specificity. Finally, such theories often fail to protect those whom society has traditionally not protected. Although each of these problems is shared, to some degree, by all tradition-based theories of fundamental rights adjudication, Justice Scahia's theory exacerbates these problems to such a great degree that his approach becomes unworkable and conceptually unsound.

\section{A. Defining Tradition}

Justice Scahia accepts that the term "hiberty" in the due process clause protects more than just the freedom from physical restraint. ${ }^{59}$ Given this determination, Justice Scalia advocates the use of tradition, ${ }^{60}$ and indeed the most specific relevant tradition, ${ }^{61}$ as a guide to interpret the term "hiberty," "lest the only limits to . . . judicial intervention become the predilections of those who happen at the time to be Members of [the] Court."62

Tradition, however, is at best an illusory limitation so long as judges are free to decide for themselves what does and does not qualify as a

56. Michael H. v. Gerald D., 491 U.S. 110, 122 (1989) (quoting Snyder v. Massachusetts, 291 U.S. 97,105 (1934)).

57. $C f$. id. at 138 (Brennan, J., dissenting) (The plurality's approach forces the Court "to identify the point at which a tradition becomes firm enough to be relevant to our definition of liberty and the moment at which it becomes too obsolete to be relevant any longer.").

58. Cf. id. at 137 (Brennan, J., dissenting) ("Because reasonable people can disagree about the content of particular traditions... the plurality has not found the objective boundary that it secks.").

59. See id. at 121.

60. See id. at 122.

61. See id. at 127 n.6.

62. Id. at 121 (quoting Moore v. City of East Cleveland, 431 U.S. 494, 502 (1977)). 
tradition. For example, in Bowers v. Hardwick, ${ }^{63}$ the Court cited ancient proscriptions against sodony as well as the fact that "until 1961 all 50 States outlawed sodomy, and [in 1986], 24 States and the District of Columbia continue[d] to provide criminal penalties for sodomy performed in private and between consenting adults" as evidence of a tradition disapproving of consensual homosexual sodomy. ${ }^{64}$ However, one could argue that because twenty-three states repealed their prohibitions agamst sodoiny between 1961 and $1986,{ }^{65}$ a new tradition respecting sexual autonomy and a right to engage in homosexual sodomy had been founded.

When defining "our traditions," it is unclear whether ancient custoins should take precedence over modern trends, whether the "traditions" of France or of Africa should be considered as well as those of England, or whether minority custons should be given any weight whatsoever. One might wonder if the answer a jurist provides to these questions will be influenced by the outcome he seeks to achieve. Dissenting in Griswold v. Connecticut, ${ }^{66}$ Justice Hugo Black noted this problem: "[T] which the Court can use to determine what traditions are rooted in the '[collective] conscience of our people.'" Justice Black concluded that judges would be unable to avoid considering "their personal and private notions" im determining what was a tradition. ${ }^{67}$ If Justice Black was right, then Justice Scalia's emphasis on tradition as the alpha and the ornega in defining the boundaries of due process provides a limitation on the judiciary only to the extent that individual jurists are limited in their creativity.

Unlike other tradition-based approaches to fundamental rights adjudication-which recognize tradition as helpful in defining a protected liberty interest, but do not use tradition as the sole determining factor ${ }^{68}$ Justice Scalia's approach inakes the existence of a societal tradition, which protects or dernes protection to an asserted interest, the determining factor in defining the scope of a protected liberty interest. Thus, to the extent that a jurist's definition of "tradition" depends upon his "personal and private notions," Justice Scalia's exclusive focus upon tradition ensures that his approach is a wholly illusory limitation on the judiciary.

63. 478 U.S. 186 (1980).

64. Id. at 193-94.

65. See Survey on the Law, Survey on the Constitutional Right to Privacy in the Context of Homosexual Activity, 40 U. Miami L. Rev. 521, 526-27 (1986).

66. 381 U.S. 479, 519 (1965) (Black, J., dissenting).

67. Id.

68. See, e.g., Michael H. v. Gerald D., 491 U.S. 110,140 (1989) (Brennan, J., dissenting) (arguing that the plurality is misguided in ignoring the reasons for limiting the role of tradition in constitutional interpretation). 


\section{B. Determining the Most Narrow Relevant Tradition}

Justice Scalia's "insistence that the asserted liberty interest be rooted in history and tradition" 69 would be probleinatic even if there were an agreed-upon definition of "tradition," because it requires that jurists become historians and sociologists. The problems faced by a jurist/historian/sociologist who scours the pages of history in search of our inost specific relevant traditions are greater than the probleins faced by the interpretivist jurist who struggles to divine the original intent of the Constitution's Framers. ${ }^{70}$ Whereas the interpretivist jurist struggles to understand the handful of hoinogenous inen who wrote the United States Constitution, the jurist/historian/sociologist who atteinpts to faithfully adjudicate a claimed hiberty interest under Justice Scalia's theory inust struggle to understand and articulate the deeply rooted traditions of a diverse, constantly changing society. Once the jurist/historian/sociologist uncovers the area of tradition that speaks to the claimed liberty interest, he must dig deeper to be certain that he has found the inost specific relevant tradition.

Justice Scalia's theory of fundamental rights adjudication is susceptible to the criticisms leveled at interpretivisin. An obvious attack on any theory that calls for an inquiry into the intent of the Framers is that the intent of the Framers is unknowable or at least not directly accessible to a judge. ${ }^{71}$ Even inore problenatic, the deeply rooted traditions of this nation are not directly accessible to a jurist, but instead inust be constructed by him.

Critics of interpretivism argue that the theory is fundamentally flawed because determinate continuities can not be identified froin history, yet "[i]nterpretivism requires that judges today be able to trace historical continuities between the institutions the frainers knew and those that contemporary judges know."72 This difficulty is compounded, critics argue, because interpretivists fail to appreciate that the meanings attached to behiefs and intentions derive from the societal context in which those behefs and intentions arose. ${ }^{73}$ Thus, one cannot understand the meanings that our forebears attached to their behefs and intentions without first understanding the society in which they lived. One cannot

69. Id. at 123.

70. Interpretivists believe that judges "should confine themselves to enforcing norms that are stated or clearly implicit in the written Constitution." J. ELY, DEMOCRACY AND DISTRUST 1 (1980). Interpretivists rely upon the intent of the Constitution's Framers to guide them in their searcli for these norms. See Tuslnet, Following the Rules Laid Down: A Critique of Interpretivism and Neutral Principles, 96 HARv. L. REV. 781, 782 (1983).

71. See Tushnet, supra note 70 , at 793.

72. Id. at 824-25.

73. See id. at 797. 
"grasp historical parts without embracing the historical whole."74 In short, interpretivism as a theory fails to appreciate that people are a product of their environment.

A subset of interpretivism, the hermeneutic approach, ${ }^{75}$ tries to remedy this shortcoming of interpretivisin by attempting to elnbrace the historical whole. Adherents of this approach argue that, because beliefs have meaning only in relation to the context in which they arose, to understand the intentions or traditions of tlose wlio lived in a previous age one must first reconstruct that age. One "must enter the minds of his or her subjects, see the world as they saw it, and understand it in their own terms."76

Critics argue that the hermeneutic approach also fails as a limitation on the judiciary. When a jurist reconstructs the world of the past, he creatively constructs it by using his own contemporary world view: "For such creativity is the only way to bridge the gaps between that world and ours. The past . . . is in its essence imdeterminate . . . ."77

These criticisms of interpretivism apply to any theory of fundamental rights adjudication grounded in tradition. The social mores of a people undoubtedly change over time and not only influence but are influenced by the environment in which they exist; thus, today's jurists cannot directly access the deeply rooted traditions of our nation. To understand these traditions, jurists must see the world as our forebears saw it. Yet, those jurists who seek to reconstruct the past undoubtedly will be biased by their own world view. Therefore, built into any theory of fundamental rights adjudication grounded in tradition is the uncertamty of whether jurists have correctly interpreted our predecessor's behefs and custoins. However, because broader principles are more easily apphed and more certainly ascertainable than are narrower principles, Justice Scalia's approach exacerbates the uncertainty inherent in any traditionbased analysis by requiring that jurists utilize the most narrow relevant tradition to define the scope of a liberty interest. To see this dilemina, one need only look at the assumptions upon which Justice Scalia rested his analysis in Michael $H$.

In Michael $H$., Justice Scalia cited the cominon law presumption of legitimacy as support for the notion that "our traditions have protected the marital family (Gerald, Carole, and the child they acknowledge to be

74. Id.

75. In the hermeneutic tradition, "historical knowledge is seen as "the interpretive understanding of [the] meanings' that actors give their actions." Id. at 798 (quoting R. KEAT, THE PoLITICS of Social Theory: Habermas, Freud, aNd the Critique of Positivism 3 (1981)).

76. Tushnet, supra note 70 , at 798.

77. Id. at 800 . 
theirs) against the sort of claim Michael asserts."78Yet, the common law upon which Justice Scalia's analysis rehes developed at a time when blood tests to establish paternity were unknown. ${ }^{79}$ Thus, we do not know what the 17th century English jurists who enforced the common law would have done if confronted with a blood test showing a $98.07 \%$ probability that Michael $\mathrm{H}$. was the father of Victoria. The common law presumption of legitimacy, therefore, did not necessarily reflect a preference for the marital family over the parental relationship. This presumption may have arisen merely because of a recognition that a child born into an existing inarriage is inore often than not a child of the marriage.

In his plurality opimion, Justice Scalia noted that the common law presumption of legitimacy could be rebutted ouly if "a husband was incapable of procreation or had had no access to his wife during the relevant period." 80 Justice Scalia argued that this fact evidenced a narrow tradition that demed protection to the relationship between a putative father and his claimed illegitimate child adulterously conceived. ${ }^{81}$ However, one can interpret this fact just as plausibly as evidence of a narrow relevant tradition that protected the relationship between a putative father and his claimed illegitimate child adulterously conceived whenever there was evidence that the husband of the marriage to whom the child was born was almost certainly not the father of the child. How one views this fact is likely to be influenced by the outcome one seeks to achieve.

One can confidently characterize the common law presumption of legitimacy and the severe restrictions on rebuttal of the presumption as evidence of a tradition respecting the family. Further, it is plausible to argue, as did Justice Scalia, that the presumption and restrictions on rebuttal of the presumption reflect a tradition that prefers the marital fainily over the biological parent-child relationship. However, an equally plausible argument can be made that these saine facts reflect respect for the biological parent-child relationship whenever the putative father can prove his biological relationship. Thus, the broader tradition can be stated with confidence, whereas the narrower "traditions" are uncertain. Therefore, Justice Scalia's theory, which depends on the unknowable most narrow relevant tradition, is unworkable.

\section{Protecting Minority Interests}

Even if it were possible to define and identify the "most narrow relevant tradition" applicable to a claimed liberty interest, it would be a mis-

78. Michael H. v. Gerald D., 491 U.S. 110, 124 (1989).

79. See id. at 140 (Brennan, J., dissenting).

80. Id. at 124.

81. Id. at $124-25$. 
take for the Court to adopt Justice Scalia's approach and use such a tradition to define the scope of due process protection. The fourteenth amendment was meant to protect minorities from oppression by the majority. ${ }^{82}$ Justice Scalia's approach, because it focuses solely on whether a claimed liberty interest finds support in the most narrow relevant tradition, is conceptually at odds with this goal. Under Justice Scalia's approach, it is the conventional morality of the majority that defines tradition. Any analytical framework that entrusts tlie liberties of minorities solely to the conventional morality of the majority is constitutionally unsatisfactory because conventional morality is often hostile to the interests of minorities. ${ }^{83}$ As Laurence Tribe has noted: "[A]ttempts to ground constitutional rights of privacy or personhood in conventional morality ... are helpful but have inherently limited power. For we are talking, necessarily, about rights of individuals or groups against the larger community, and against the majority . . . " "84 A close examination of Justice Scalia's approacli demonstrates that his theory fails to protect minority riglits against infringement by the larger community.

An important means of protectimg minorities against the larger community is the requirement read into the fourteentli amendment that the state show that the infringement of a fundainental liberty interest is necessary to serve a compelling government interest. ${ }^{85}$ Justice Scalia's use of

82. More specifically, the fourteenth amendment was intended to protect blacks from discrimination by the white majority. E.g., CONG. GLOBE, 39th Cong., 1st Sess. 2459 (1860) (statement of Rep. Stevens) ("Unless the Constitution should restrain them those [Southern] States will all, I fear, keep up this discrimination, and crush to death the hated freedmen."). The framers of the fourtecnth amendment viewed it as a broader restatement of the Civil Rights Act of $1866 \mathrm{~m}$ a form immune from national legislative repeal. E.g., CoNG. GLOBE, 39th Cong., 1st Sess. 2462 (1866). According to Representative Garfield:

The civil rights bill is now a part of the land. But every gentleman knows that it will cease to be a part of the law whenever the sad moment arrives when that gentleman's [Rep. Finck's] party comes into power. It is precisely for that reason that we propose to lift that great and good law above the reach of political strife, beyond the reach of the plots and machinations of any party, and fix it in the serene sky, in the eternal firmament of the Constitution, where no storm of passion can shake it and no cloud can obscure it.

Id. The Civil Rights Act of 1866 had as its purpose to extend to black people the same civil rights as white people enjoyed. E.g., CoNG. GLOBE, 39th Cong., 1st Sess. 474 (1866). Senator Trumbull stated that:

Since the abolition of slavery, the Legislatures which have assembled in the insurrectionary States have passed laws relating to the freedmen, and in nearly all the States they have discrinmated against them. They deny them certain rights, subject them to severe penalties, and still impose upon them the very restrictions which were imposed upon them in consequence of the existence of slavery, and before it was abolished. The purpose of the bill under consideration is to destroy all these discriminations, and to carry into effect the Id. [thirteenth] amendment.

83. See supra note 53.

84. L. Tribe, American Constitutional LAW § 15-3, at 1311 (2d ed. 1988).

85. See Carey v. Population Servs. Int'l, 431 U.S. 678, 686 (1977). 
the most specific relevant tradition to define the scope of a protected liberty interest enables the state to infringe a previously established protected hiberty interest without any showing by the state that the infringement is necessary to serve a coinpelling government interest. The plurality's reasoning in Michael $H$. illustrates this point.

Before Michael H., the Supreme Court examined the extent to which a natural father's biological relationship with his illegitimate child receives protection under the due process and equal protection clauses of the Constitution in four cases: Stanley v. Illinois, ${ }^{86}$ Quilloin v. Walcott, ${ }^{87}$ Caban v. Mohammed, ${ }^{88}$ and Lehr v. Robertson. ${ }^{89}$ One can convincingly argue that Stanley, Quilloin, Caban, and Lehr together hold that a father who has demonstrated responsibility for his biological child has a constitutionally-protected liberty interest in his relationship with that child. 90 Under Justice Scalia's approach, one can adopt this interpretation of Stanley, Quilloin, Caban, and Lehr, yet still find that notwithstanding the fact that Michael has shown responsibility for his biological child, Victoria, he has no constitutionally-protected liberty interest in his relationship with her. ${ }^{91}$

86. 405 U.S. 645 (1972).

87. 434 U.S. 246 (1978).

88. 441 U.S. 380 (1979).

89. 463 U.S. 248 (1983).

90. The Supreme Court held in Stanley that an unwed father's "interest in retaining custody of his children [was] cognizable and substantial," 405 U.S. at 652, and that the interest of any man "in the children he has sired and raised, undeniably warrants deference and, absent a powerful countervailing interest, protection." Id. at 651 (emphasis added). In Quilloin, the Court held that a Georgia statute that allowed the adoption of an illegitimate child without the natural father's consent did not violate the due process rights of the father who had "never exercised actual or legal custody over his child, and thus [had] never shouldered any significant responsibility with respect to the daily supervision, education, protection, or care of the child." 434 U.S. at 256. In Contrast, the Caban Court held unconstitutional a statute similar to the one it had upheld in Quilloin. The Court held that the statute as applied to an unwed father who had participated in the care and support of his children was violative of the equal protection clause of the fourteenth amendment. 441 U.S. at 391. Finally, in Lehr, the Court held that neither the due process nor the equal protection clauses of the fourteenth amendinent gave an unwed father the right to be heard before his child could be adopted where the unwed father had never demonstrated any significant comnitment to a custodial, personal, or financial relationship with his child. 463 U.S. at 265-68. In his opinion for the Court, Justice Stevens noted:

The significance of the biological connection is that it offers the natural father an opportunity that no other inale possesses to develop a relationship with his offspring. If he grasps that opportunity and accepts some ineasure of responsibility for the child's future, he may enjoy the blessings of the parent-child relationship and inake uniquely valuable contributions to the child's development. If he fails to do so, the Federal Constitution will not automatically compel a State to listen to his opinion of where the child's best interests lie. Id. at 262.

91. Indeed, in his plurality opinion in Michael H. v. Gerald D., Justice Scalia acknowledged that in Lehr the Court had recognized that "[t]he significance of the biological conneetion [between a putative father and his claimed illegitimate child] is that it offers the natural father an opportunity that no other unale possesses to develop a relationship with his offspring." 491 U.S. 110, 128-29 
The Court's existing precedents are rendered irrelevant by Justice Scalia's insistence that "the most specific level at which a relevant tradition protecting, or denying protection to, [an] asserted right can be identified"92 defines the scope of a hiberty interest. The child in Michael H., unlike the children in Stanley, Quilloin, Caban and Lehr, was adulterously conceived. Justice Scalia argues that our society has a tradition that denies paternity rights to adulterous fathers. ${ }^{93}$ This tradition, Justice Scalia argues, is more specific than the tradition protecting the estabhished relationship between a biological father and his child recognized in the Stanley/Lehr line of cases. ${ }^{94}$ Thus, the more specific tradition denying recognition to adulterous fathers defines the scope of Michael's hiberty interest in his relationship with his child.

This is not to say that under Justice Scalia's approach the fact that Michael's child was adulterously conceived acts as a limitation upon the liberty interest that the Supreme Court previously recognized in the Stanley/Lehr line of cases. Rather, under Justice Scalia's theory the fact that Michael's child was adulterously conceived means that Michael has no liberty interest in his relationship with her. To state the point another way, Michael has absolutely no liberty interest upon which to place a limitation.

The importance of this distinction lies in the degree of scrutiny that the Court apphes to laws that impinge upon a protected hiberty interest. A statute that impinges upon a fundamental right can withstand constitutional scrutiny only upon a clear showing by the state that the burden imposed is necessary to protect a compelling state interest. ${ }^{95}$ The Court will not find a burden to be necessary unless the legislature has drawn the statute as narrowly as possible while still protecting the coinpelling interest. 96 Conversely, a law that does not infringe upon a liberty interest will withstand constitutional scrutiny if it is rationally related to a legitimate state interest. ${ }^{97}$ Under Justice Scaha's approach, because Michael has no

(quoting Lehr, 463 U.S. at 262). Furthermore, Justice Scalia acknowledged that the Court in Lehr "assumed that the Constitution might require some protection of that opportunity." Id. at 129 (citing Lehr, 463 U.S. at 262-65). Nonetheless, Justice Scalia argued, "Where, however, the child is born into an extant marital family, the natural father's unique opportunity conflicts with the similarly unique opportunity of the husband of the marriage; and it is not unconstitutional for the State to give categorical preference to the latter." $I d$.

92. Id. at 128 n.6.

93. Id. at 129 n.7.

94. Id. at 123-24.

95. See Carey v. Population Servs. Int'1, 431 U.S. 678, 686 (1977); Roe v. Wade, 410 U.S. 113, 155 (1973).

96. See Carey, 431 U.S. at 686.

97. See Bowers v. Hardwick, 478 U.S. 186, 196 (1986); United States v. Carolene Prods. Co., 304 U.S. 144 (1938). 
constitutionally-protected liberty interest in his relationship witl his daugliter (despite having satisfied the prerequisites that the Supreme Court previously enunciated for the enjoyinent of such a liberty interest), the Court need not ask whether the state's interest in protecting the marital union is conpelling. Further, the Court avoids an inquiry into whether the state can protect this interest in a narrower way than by denying a putative father who has developed a relationship with his putative child any possibility of being declared the father of the child. Instead, the Court need only ask whether the state statute is rationally related to protecting the niarital union. This result occurs because Justice Scalia's approach coinbines a liberty interest enjoyed by the majority (the right to preserve a developed relationship with a natural child) with a characteristic that distinguislies the person asserting the liberty interest froin the niajority (the father adnlterously conceived the child) to arrive at a conflated liberty interest (the right to preserve a relationship with an adulterously conceived child).

The principal flaw in Justice Scalia's theory is not that his approach defines "liberty" narrowly, but rather that, regardless of how one defines liberty, his approach denies minorities the protected liberties enjoyed by the inajority. The best ineans of demonstrating the error in Justice Scalia's reasoning is to liypothesize that the tern "liberty" in the due process clause only enconipasses the freedon from physical restraint. Still, Justice Scalia's approach would discriminate against minorities.

For example, a mental patient held against his will who asserts his right to physical liberty will find that, under Justice Scalia's approach, he is actually asserting the right to be pliysically free while mentally ill. Under Justice Scalia's approach, no such interest will be recoguized as long as the state can show that it has traditionally infringed upon the physical liberty right of the mentally ill.

In 1975, the Supreme Court adjudicated the claim of a mental patient who asserted that his right to pliysical liberty had been violated. In $O^{\prime}$ Connor v. Donaldson, ${ }^{98}$ a former mental patient (who was confined to a state lospital for nearly fifteen years) brought an action for damages under section $1983^{99}$ against the lospital superintendent who had refused to release him. The former patient claimed that because he was dangerous to no one, ${ }^{100}$ the superintendent's refusal to release him "deprived

98. 422 U.S. 563 (1975).

99. 42 U.S.C. $\$ 1983$ (1988) (providing a civil remedy to plaintiffs who establish a violation of a federal constitutional or statutory right by one acting under color of state law).

100. According to $O$ 'Connor, "[t]he testimony at the trial demonstrated, without contradiction, that [the former mental patient] had posed no danger to others during his long confinement, or indeed at any point in his life." 422 U.S. at 568. 
him of his constitutional right to hiberty."101 Despite the deeply rooted American tradition of locking away the mentally ill in institutions, almshouses, and jails, ${ }^{102}$ the Court did not frame the issue presented as whether the superintendent had violated the patient's right to be free while mentally ill. Rather, the Court stated "[a]s we view it, this case raises a single, relatively simple, but nonetheless important question concerning every man's constitutional right to liberty." 103 The Court held that the trial court had properly concluded that the superintendent had violated the former mental patient's constitutional right to freedom. ${ }^{104}$

The $O^{\prime}$ Connor Court, in recognizing the mental patient's right to physical hiberty, did not compound societal prejudices and the asserted biberty interest. In contrast, Justice Scalia's approach makes societal prejudices the controlling factor in defining the scope of liberty to be enjoyed by minorities under the due process clause. This approach adversely affects all minorities-even blacks, the minority that the framers of the fourteenth amendment most wanted to protect.105 For example, under his formulation, an interracial couple who in the 1960s asserted the right to marry ${ }^{106}$ would have been demed that right because the majority had traditionally infringed the ability of interracial couples to marry. ${ }^{107}$

In fact, however, when an interracial couple asserted a hiberty interest in the right to marry, the Supreine Court rejected both the reasoning and the result inherent in Justice Scalia's footnote 6 approach. In Loving v. Virginia, a black woman and her white husband, both of whom had been convicted of violating Virginia's ban on interracial marriage and sentenced to one year in jail, challenged the constitutionality of Virginia's

101. Id. at 565 .

102. See A. Deutsch, The Mentally Ill in America 38-54, 114-31 (2d ed. 1949) (history of care and treatment since the colonial period); D. ROTHMAN, THE DisCOVERY OF THE AsYLUM 26595 (1971) (custodial qualities of post-1850 asylums).

103. O'Connor, 422 U.S. at 573.

104. Id. at 576-77. The Court remanded the case to enable the court of appeals to determine if the trial court had rendered inadequate instructions with regard to the superintendent's claimed reliance on state law. Id.

105. See supra note 82.

106. To be precise, under Justice Scalia's theory, an interracial couple could not assert the right to marry but, instead, must assert the right to enter into an interracial marriage.

107. See Loving v. Virginia, 388 U.S. 1, 6 n.5 (1967) (The Court listed 16 states that currently outlawed interracial marriages: Alabama, Arkansas, Delaware, Florida, Georgia, Kentucky, Louisiana, Mississippi, Missouri, North Carolina, Oklahoma, South Carolina, Tennessee, Texas, Virginia, and West Virginia. It further noted that during the previous 15 years, 14 states had repealed laws outlawing interracial marriages: Arizona, California, Colorado, Idaho, Indiana, Maryland, Montana, Nebraska, Nevada, North Dakota, Oregon, South Dakota, Utah, and Wyoming.). 
anti-miscegenation statutes. ${ }^{108}$ Defending the statutes, the Commonwealth of Virginia rehed heavily on the fact that at the time the states ratified the fourteenth amendment most of the states had anti-miscegenation statutes. ${ }^{109}$ The Court noted that fifteen states in addition to Virgima currently had anti-miscegenation statutes that prohibited and punished marriage on the basis of racial classifications. ${ }^{110}$ The Court further noted that as recently as 1952, thirty states had laws outlawing interracial marriages. ${ }^{111}$ Nevertheless, the Court held that Virginia's antimiscegenation statutes violated both the equal protection and due process clauses of the fourteenth amendment. ${ }^{112}$ The Court held that the statutes violated the due process clause of the fourteenth amendment by impinging upon "[t] he freedom to inarry" which "has long been recognized as one of the vital personal rights essential to the orderly pursuit of happiness by free men."113

In Loving, the Court clearly did not "refer to the inost specific level at which a relevant tradition protecting, or denying protection to, the asserted right can be identified."114 If it had, the Court would have recognized that prohibitions against miscegenation are deeply "rooted in the traditions and conscience of our people"115 and would have denied protection to the asserted hiberty interest in inarrying a person of a different race.

The Supreme Court in Loving recognized that "liberty" encompasses more than the freedom to do what the majority allows. Justice Scalia does not accept this interpretation of liberty; instead, he would deny recognition to an asserted hiberty interest whenever "a societal tra-

108. Id. Richard Loving and Mildred Jeter had been convicted of violating section 20-58 of the Virginia Code which provided:

If any white person and colored person shall go out of this State, for the purpose of being married, and with the intention of returning, and be niarried out of it, and afterwards return to and reside in it, cohabiting as man and wife, they shall be punished as provided in $\$ 20-59$, and the marriage shall be governed by the same law as if it had been solemnized in this State. The fact of their cohabitation here as nan and wife shall be evidence of their marriage.

VA. CODE ANN. $\$ 20-58$ (1960) (repealed 1968).

Section 20-59 of the Virginia Code provided:

If any white person intermarry with a colored person, or any colored person intermarry with a white person, he shall be guilty of a felony and shall be punished by confineinent in the penitentiary for not less than one nor more than five years.

Id. at $\$ 20-59$ (1960) (repealed 1968).

109. Brief on Behalf of Appellee at 28-29, Loving v. Virginia, 388 U.S. 1 (1967) (No. 395).

110. Loving, 388 U.S. at 6 n.5.

111. Id.

112. Id. at 12.

113. Id.

114. Michael H. v. Gerald D., 491 U.S. 110, 127 n.6 (1989).

115. Id. at 122 (quoting Snyder v. Massachusetts, 291 U.S. 97, 105 (1934)). 
dition of enacting laws den[ies] the interest."116 Such an approach runs counter to the purpose of the framers of the fourteenth amendment, who imtended to ensure states did not infringe upon minorities' enjoyment of liberties that the majority had traditionally enjoyed. ${ }^{117}$

\section{CONCLUSION}

In his effort to strike a blow against judicial activism, Justice Scalia ignores the principle at the core of the fourteenth amendment-protection of minority interests. Indeed, far worse than tossing out the baby with the bath water, Justice Scalia tosses out the baby but keeps the bath water. The principal effect of Justice Scalia's approach to fundamental rights adjudication is not to constram the judiciary from declaring new hiberty interests, but rather to deny minorities the protection of estabhished hiberty interests.

The practical difficulties arising under Justice Scalia's formulation ensure that his approach, if adopted by the Court, would serve as no constraint on the judiciary. To give meaning to the term "tradition" and to accurately discern the contours of our people's deeply rooted traditions are difficult, perhaps impossible, tasks. By relying exclusively on the most narrow relevant tradition, Justice Scalia's approach fails as a limitation in practice because it requires jurists to delineate the traditions of our society with greater precision than they are capable.

Even if Justice Scalia's approach to fundanental rights adjudication were a practical constraint on the judiciary, it would still be illegitimate and ill-advised. Justice Scalia's attempt to constrain the judiciary amounts to an arbitrary hine that cuts off protection for fundamental liberty interests. According to Moore v. City of East Cleveland, "Appropriate himits on substantive due process come not from drawing arbitrary lines but rather from careful 'respect for the teachings of history [and] solid recognition of the basic values that underlie our society." "118 As long as the due process clause of the fourteenth amendment continues to protect only those interests that our society has traditionally protected, courts should not look to tradition as the sole means of defining the scope of a liberty interest. Tradition should be merely the means for determining whether the values implicated by a claimed liberty interest have enjoyed protection in the past and thus whether a claimed liberty interest merits further consideration. The Court must not "close [its] eyes to the basic reasons why certain rights have been accorded shelter under the

116. Id. at 122 n.2.

117. See supra note 82 and accompanying text.

118. 431 U.S. 494, 503 (1977) (quoting Griswold v. Connecticut, 381 U.S. 479, 501 (1965) (Harlan, J., concurring)). 
Fourteenth Amendment's Due Process Clause," but should "apply[ ] the force and rationale of these precedents to the ... choice involved in [a] case."119

Edward Gary Spitko

119. Id. at 501 . 